\title{
A study on relationship between internal auditing and quality of financial statement
}

\author{
Maryam Abulghasemi Komeleh $^{\mathrm{a}}$ and Mansour Garkaz ${ }^{\mathrm{b}^{*}}$
}

${ }^{a}$ Department of Accounting, Science and Research Branch, Islamic Azad University, Golestan, Iran

${ }^{b}$ Department of Accounting, Aliabad Katoul Branch, Islamic Azad University, Aliabad Katoul, Iran

\section{CHRONICLE ABSTRACT}

Article history:

Received January 20, 2014

Accepted 5 July 2014

Available online

August 232014

Tehran Stock Exchange

Quality of statement

Internal auditing

\begin{abstract}
The primary objective of most financial statements is to provide a concentrated as well as categorized reports on financial performance and flexibility to help decision makers reach suitable financial decisions. This paper presents an empirical investigation to study the relationship between internal auditing and quality of financial statements on selected firms listed on Tehran Stock Exchange. The proposed study selects 140 firms over the period 20082012. Using some regression technique, the study has determined that there was a positive and meaningful relationship between firms with internal auditing in their activities and quality of financial statements.
\end{abstract}

\section{Introduction}

Internal auditing is considered as an independent, objective assurance and consulting activity designed to add value and to improve firms' operations. It assists firms to accomplish their objectives by bringing a systematic, disciplined method to assess and to improve the effectiveness of risk management, control, and governance processes (Fama \& French, 1993; Raghunandan et al., 2001). Internal auditing is a catalyst for improving firms' governance, risk management and management controls by giving insight and recommendations based on analyses and evaluations of data and business processes (Healy \& Palepu, 2001). With commitment to integrity and accountability, internal auditing gives value to governing bodies and senior management as an objective source of independent advice. The scope of internal auditing within firms is extensive and may include topics such as an organization's governance, risk management and management controls (Krishnan, 2005). Internal auditing may also include conducting proactive fraud audits to determine potentially fraudulent acts; participating in fraud investigations under the direction of fraud investigation professionals, and conducting post investigation fraud audits to detect control breakdowns and to establish financial loss.

*Corresponding author.

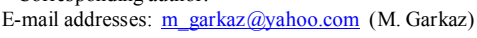


Doyle et al. (2007) investigated the relationship between accruals quality and internal controls using 705 firms that disclosed at least one material weakness from August 2002 to November 2005 and reported that weaknesses were generally associated with poorly estimated accruals, which were not realized as cash flows. They reported that this relation between weak internal controls and lower accruals quality was driven by weakness disclosures, which was associated with overall companylevel controls, which could be more difficult to "audit around." They also reported no such relationship for more auditable, account-specific weaknesses. Nevertheless, they reported similar results using four additional measures of accruals quality: discretionary accruals, average accruals quality, historical accounting restatements, and earnings persistence.

\section{The proposed study}

This paper presents an empirical investigation to study the relationship between internal auditing and quality of financial statements on selected firms listed on Tehran Stock Exchange. The proposed study selects 140 firms over the period 2008-2012. To select the firms, only firms whose financial statements were available were selected and there should not be any three-month-long interruption on their shares activities. In addition, no financial or holding firm was permitted to this study. The accruals $\left(A_{c c r}\right)$ is calculated as follows,

$$
\text { Accr }_{i, t}=\alpha_{0}+\alpha_{1}\left(1 / T A_{i, t-1}\right)+\alpha_{2} \Delta R E V_{i, t}+\alpha_{3} P P E_{i, t}+\alpha_{4} R O A_{i, t}+\varepsilon_{i, t}
$$

where Accr $_{i, t}$ is estimated as follows,

$\underline{\Delta \text { CurrentAssets }-\Delta \text { Cash }-\Delta \text { CurrentLiabilities }- \text { Depreciation }}$.

\section{TotalAssets}

Let $\triangle R E V_{i, t}$ be the ratio of net revenue divided by total assets, $P P E_{i, t}$ be the ratio of net equipment divided by total assets and $R O A_{t}$ be the return on assets. Discretionary accruals (DisTA) is calculated by measuring the absolute values of residuals in Eq. (1) and then we multiplying by negative one. The more negative value represents better quality of financial statements. We may also use the method suggested by Dechow and Dichev (2002) to calculate the quality of earnings as follows,

$W C A_{i, t}=\alpha_{0}+\alpha_{1} O C F_{i, t-1}+\alpha_{2} O C F_{i, t}+\alpha_{3} O C F_{i, t+1}+\alpha_{4} \Delta \operatorname{Re} v_{i, t}+\alpha_{5} P P E_{i, t}+\alpha_{6} D O C F_{i, t}+\alpha_{7} O C F_{i, t} \times D O C F_{i, t}+\varepsilon_{i, t}$

where $W C A_{i t}$ is the working capital accruals, which is calculated as follows,

\section{$\Delta$ CurrentAssets $-\Delta$ Cash $-(\Delta$ CurrentLiabilities $-\Delta$ CurrentDebt $-\Delta$ TaxPayables $)$}

\section{TotalAssets}

In addition, in Eq. (3), OCF represents operating cash flow, Rev states the total revenue, DOCF is a dummy variable, which is one if money is going out and zero, otherwise. The residuals of Eq. (3) is multiplied by negative one and it yields DisWCA as discretionary working capital accruals. The last model was originally developed by Wallman (1996) and is as follows,

$\Delta A R_{i, t}=\alpha_{0}+\alpha_{1} \Delta \operatorname{Re} v_{i, t}+\varepsilon_{i, t}$

where $\Delta A R_{i, t}$ represents the change in receivable accounts and $\Delta R e v_{i, t}$ represents the change in net profit divided by total assets and the procedure of calculating discretionary accruals is the same as the previous models. To examine the main hypothesis of this paper we use the following model,

$(\text { DisTA,DisWCA,Dis Re } v, \text { AccrCash })_{i, t}=\alpha_{0}+\alpha_{1} I A Q_{i, t}+\alpha_{2} B O D Q_{i, t}+\alpha_{3} C G_{i, t}+\alpha_{4} A Q_{i, t}$ $+\alpha_{5}$ LASSET $_{i, t}+\alpha_{6} I N V_{i, t}+\alpha_{7} L_{E V_{i, t}}+\alpha_{8}$ CFO $_{i, t}+\alpha_{9} L_{A G E_{i, t}}+\alpha_{10} S G R O W T H_{i, t}+\varepsilon_{i, t}$

where 
$\operatorname{AccrCash}_{i, t}=-\ln \left(\frac{|A c c r|}{|O C F|}\right)$.

In addition, $I A Q_{i, t}$ is one if firm has signed a contract for internal auditing and zero, otherwise, $B O D Q_{i, t}$ is one if there is a person with the financial background in board of directors and zero, otherwise, and finally $C G_{i, t}$ is one if the average number of corporate governance is greater than an average number and zero, otherwise. Table 1 demonstrates the summary of some basic statistics.

Table 1

The summary of some basic statistics for the first model

\begin{tabular}{cccccc|cc}
\hline & \multicolumn{3}{c}{ First model } & \multicolumn{2}{c}{ Second model } \\
\hline Variable & $R O A_{t}$ & $P P E_{i, t}$ & $\Delta R E V_{i, t}$ & $1 / T A_{i, t-1}$ & $A c c r_{i, t}$ & $\Delta R E V_{i, t}$ & $\Delta A R_{i, t}$ \\
\hline Number & 700 & 700 & 700 & 700 & 700 & 700 & 700 \\
Mean & 0.156 & 0.236 & 0.144 & 0.000 & 0.099 & 0.144 & 0.010 \\
Median & 0.131 & 0.196 & 0.110 & 0.000 & 0.069 & 0.110 & 0.020 \\
Mode & 0.320 & 0.180 & 0.000 & 0.000 & 0.030 & 0.000 & 0.000 \\
Standard deviation & 0.116 & 0.158 & 0.130 & 0.000 & 0.106 & 0.130 & 0.392 \\
Skewness & 1.212 & 0.700 & 1.736 & 34.539 & 2.574 & 1.736 & -1.283 \\
Kurtosis & 1.532 & -0.374 & 4.106 & 1225.000 & 9.981 & 4.106 & 316.573 \\
Range & 0.650 & 0.690 & 0.920 & 0.000 & 1.000 & 0.920 & 16.000 \\
Min & 0.000 & 0.000 & -0.020 & 0.000 & -0.090 & -0.020 & -8.000 \\
Max & 0.660 & 0.700 & 0.890 & 0.000 & 0.910 & 0.890 & 8.000 \\
Q25 & 0.072 & 0.105 & 0.053 & 0.000 & 0.029 & 0.021 & 0.053 \\
Q50 & 0.131 & 0.196 & 0.110 & 0.000 & 0.069 & 0.098 & 0.110 \\
Q75 & 0.211 & 0.351 & 0.198 & 0.000 & 0.133 & 0.185 & 0.198 \\
\hline
\end{tabular}

\section{The results}

Table 2 demonstrates the results of regression analysis for Eq. (5). The table shows the implementation of four regression models where dependent variables are DisTA, DisWCA, DisRev and AccrCash.

Table 2

The summary of regression analysis

\begin{tabular}{cccccccccccccc}
\hline & \multicolumn{3}{c}{ AccrCash } & \multicolumn{3}{c}{ DisRev } & \multicolumn{3}{c}{ DisWCA } & \multicolumn{3}{c}{ DisTA } \\
\hline & P-value & $\mathrm{t}$ & $\beta_{\mathrm{i}}$ & P-value & $\mathrm{t}$ & $\beta_{\mathrm{i}}$ & P-value & $\mathrm{t}$ & $\beta_{\mathrm{i}}$ & P-value & $\mathrm{t}$ & $\beta_{\mathrm{i}}$ \\
\hline$\alpha_{0}$ & 0.330 & 0.975 & 1.731 & 0.011 & -2.538 & -0.772 & 0.827 & -0.219 & -0.030 & 0.480 & 0.707 & 0.199 \\
IAQ & $\mathbf{0 . 0 0 0}$ & $\mathbf{3 . 0 8 1}$ & $\mathbf{1 . 0 1 0}$ & $\mathbf{0 . 0 0 0}$ & $\mathbf{3 . 4 8 6}$ & $\mathbf{0 . 9 1 0}$ & $\mathbf{0 . 0 0 0}$ & $\mathbf{3 . 1 2 9}$ & $\mathbf{1 . 0 0 1}$ & $\mathbf{0 . 0 0 0}$ & $\mathbf{3 . 4 5 5}$ & $\mathbf{1 . 0 0 9}$ \\
BODQ & 0.887 & 0.142 & 0.018 & 0.761 & -0.304 & -0.007 & 0.492 & -0.687 & -0.007 & 0.784 & -0.275 & -0.005 \\
CG & 0.443 & 0.767 & 0.096 & 0.186 & 1.324 & 0.028 & 0.138 & 1.486 & 0.014 & 0.847 & -0.193 & -0.004 \\
AQ & 0.397 & -0.848 & -0.108 & 0.444 & 0.767 & 0.017 & 0.828 & -0.217 & -0.002 & 0.526 & -0.635 & -0.013 \\
LASSET & 0.534 & -0.622 & -0.030 & 0.836 & 0.207 & 0.002 & 0.898 & 0.128 & 0.000 & 0.613 & -0.506 & -0.004 \\
INV & 0.111 & -1.595 & -0.805 & 0.510 & 0.659 & 0.057 & 0.996 & -0.005 & 0.000 & 0.931 & 0.087 & 0.007 \\
LEV & 0.801 & -0.252 & -0.102 & 0.000 & 4.030 & 0.278 & 0.076 & 1.775 & 0.055 & 0.623 & -0.492 & -0.031 \\
CFO & 0.601 & -0.524 & -0.002 & 0.262 & 1.124 & 0.001 & 0.652 & 0.452 & 0.000 & 0.540 & 0.614 & 0.000 \\
LAGE & 0.854 & -0.184 & -0.113 & 0.265 & 1.115 & 0.117 & 0.557 & -0.587 & -0.028 & 0.316 & -1.004 & -0.097 \\
SGROWTH & 0.243 & -1.170 & -0.155 & 0.748 & 0.321 & 0.007 & 0.274 & -1.096 & -0.011 & 0.003 & -3.000 & -0.063 \\
\hline Durbin- & & 2.062 & & & 2.027 & & & 1.995 & & & 2.132 & \\
Watson & & 3.633 & & & 2.708 & & & 3.812 & & & 3.206
\end{tabular}


As we can observe from the results of three regression models, Durbin-Watson values for all models are within an acceptable level. Therefore, we can conclude that there was no auto-correlation among residuals. In addition, F-value is statistically significant, which means the relationship was linear. The sign of IAQ variable is positive and t-student values for all models are statistically meaningful when the level of significance is one percent. Therefore, we can confirm the main hypothesis of the survey and conclude that there was a positive and meaningful relationship between the quality of financial statements and having internal auditing.

\section{Conclusion}

In this paper, we have presented an empirical investigation to study the relationship between the quality of financial statements and having internal auditing services in selected firms listed on Tehran Stock Exchange. The proposed study of this paper has implemented various models and the results have confirmed that there was a positive and meaningful relationship between the quality of financial statement and helping some external agencies on having internal auditing.

\section{Acknowledgement}

The authors would like to thank the anonymous referees for constructive comments on earlier version of this paper.

\section{References}

Dechow, P. M., \& Dichev, I. D. (2002). The quality of accruals and earnings: The role of accrual estimation errors. The accounting review, 77(s-1), 35-59.

Doyle, J. T., Ge, W., \& McVay, S. (2007). Accruals quality and internal control over financial reporting. The Accounting Review, 82(5), 1141-1170.

Fama, E. F., \& French, K. R. (1993). Common risk factors in the returns on stocks and bonds. Journal of financial economics, 33(1), 3-56.

Healy, P. M., \& Palepu, K. G. (2001). Information asymmetry, corporate disclosure, and the capital markets: A review of the empirical disclosure literature. Journal of Accounting and Economics, 31(1), 405-440.

Krishnan, J. (2005). Audit committee quality and internal control: An empirical analysis. The Accounting Review, 80(2), 649-675.

Raghunandan, K., Rama, D. V., \& Read, W. J. (2001). Audit committee composition, "gray directors," and interaction with internal auditing. Accounting Horizons, 15(2), 105-118.

Wallman, S. M. (1996). The future of accounting and financial reporting part II: the colorized approach. Accounting Horizons, 10, 138-148. 